\title{
Examining Student Motivation to Use a Gamified System in an Immunology and Immunization Training Course
}

Connie S. Barber, $P h D^{1}$; Konstantina Stavroulaki, $\mathrm{MS}^{2}$; Catherine D. Santanello, $P h D^{3}$

${ }^{1}$ School of Business, Department of Computer Management Information Systems

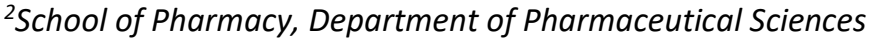

${ }^{3}$ School of Pharmacy, Department of Pharmaceutical Sciences; Southern Illinois University Edwardsville

\section{ABSTRACT}

Background: Gamification is the process of adding game elements into classroom activities to encourage student participation and motivation. Classcraft is a gamified learning system designed to integrate easily with normal classroom activities and to enhance collaboration and teamwork.

Educational activity and setting: This study explored the use of the Classcraft ${ }^{\circ}$ system in an Immunology and Immunization Training course, specifically examining students' motivation to use the system and potential impacts on their motivation.

Findings: Results showed that value and enjoyment motivated students to use Classcraft ${ }^{\circ}$. Furthermore, the ease of use of the system positively impacted students' enjoyment of the system. Students' choice regarding how much they were required to engage with the system positively impacted the value and enjoyment that they experienced with the system.

Summary: Students' demonstrated motivation to use Classcraft ${ }^{\circ}$ provides a foundation for further research into the use of gamified learning systems within pharmacy classrooms. Research is needed to understand if use of a gamified learning system positively impacts learning outcomes.

Keywords: gamification, gaming, Immunology, student engagement, Classcraft ${ }^{\circ}$

\section{INTRODUCTION}

With some exceptions, most current Pharmacy students are either Millennials (born between 1981 and 1996) or members of Generation Z (born 1997 onward). ${ }^{1}$ Technology is at the forefront of how both groups communicate and interact. ${ }^{1}$ Because of this, these students may require a more interactive approach to learning than a traditional classroom lecture can provide. ${ }^{2}$ Previous studies conducted at schools of Pharmacy have suggested that technology use in the classroom can have positive and negative effects on learning. Begley et al. reported that for non-academic purposes, the majority of faculty polled recognized significant problems with students' use of technology in the classroom. ${ }^{3}$ However, the use of appropriate, supervised technology in the right pedagogical setting can enhance student learning.

According to Shawaqfeh (using the Merriam-Webster dictionary), gamification is the process of adding games or game elements into something in order to encourage participation. ${ }^{4}$ Sera et al. define gamification, also known as serious games, game-based learning, or educational games, as the use of game mechanics to promote engagement and enjoyment of problem-solving in non-game situations. ${ }^{5}$ It is a way to digitally engage and motivate students to achieve their

Corresponding author: Catherine D. Santanello, PhD

School of Pharmacy, Department of Pharmaceutical Sciences

Southern Illinois University Edwardsville

220 University Park Drive

Edwardsville, Illinois 62026

Phone: (618) 650-5165; Email: csantan@siue.edu goals. ${ }^{5-6}$ Advantages of the use of gamification may include collaborative learning, high student motivation with increased time on task, immediate feedback, and the potential for attitude and behavior change. ${ }^{7}$ Incorporating gamification into healthcare education might enhance students' engagement in their own learning. ${ }^{4}$

Lam et al. used a virtual gaming system called Myrex to assess pharmacy student attitudes towards playing educational games in Psychiatry/Neurology courses. Students showed significant changes in attitude and satisfaction using the gaming system. ${ }^{8}$ While the majority of students agreed that the use of games effectively promoted learning with the introduction or review of new topics, Grady et al. found that students reported learning more from a traditional lecture format. ${ }^{2}$ Using a Virtual Dispensary game, students reported its application as a fun and effective learning technique, but this is not always indicative of learning outcomes. ${ }^{9}$ The literature regarding the use of technology in pharmacy education primarily focuses on student perceptions of learning. In a study to determine if games were reflective of student performance in pharmacotherapeutics courses, Dell et al. found a significant correlation between Kahoot! review scores and other course grades. ${ }^{6}$ Yet, before learning outcomes can be assessed, it is important to understand what motivates students to use gamified learning systems and what impacts those motivations.

Research in the gamification field often focuses on either the elements of the systems or student perceptions of the systems and many studies of gamification are set in business or computer science courses. ${ }^{10-14}$ To add to the body of literature in both gamification and pharmaceutical education, the current 
study examined student motivations for using the gamified learning system and how those motivations might be impacted. Classcraft ${ }^{\oplus}$ (Classcraft Studios, Inc., Canada) was chosen for this study due to its features, which allow for interaction among team members in the online setting, as well as between students and instructors in a face-to-face setting. ${ }^{15} \mathrm{Classcraft}^{\oplus}$ was designed to integrate easily with normal classroom activities and to enhance collaboration and teamwork. It was also intended to keep students continually engaged in group assignments and review sessions, which could ultimately help them use their critical thinking skills and learn complex topics in the hard sciences.

The aim of this study was to examine how PharmD students' perceived ease of use of the gamified learning system and their choice in using it impact the value and enjoyment motivations of using the system. The subsequent sections of the paper include the research model, method, results, and discussion.

\section{Research Model}

From a system perspective, students' perspectives on the gamification system were examined, as well as the tasks they were required to complete as they relate to their motivation to use the system. Specifically, ease of use of the system and a students' choice in using it were examined for their impact on the value and enjoyment that they experienced, which could ultimately enhance student learning of difficult topics in Immunology. Dependent variables of value and enjoyment were derived from literature regarding individual motivations to use gamification systems. Value refers to students' beliefs in the system's usefulness, as well as its ability to help them enhance their learning in the course and to positively impact concentration. ${ }^{16-17}$ Enjoyment in this context is defined as the factors which make computer games fun. ${ }^{18}$ Enjoyment also describes the positive reactions that individuals experience in response to the game play. ${ }^{18}$ Figure 1 provides the research model inclusive of the specific constructs that we examined. We posit that the ease of use and choice in using the system will positively impact a student's experienced value and enjoyment in the system.

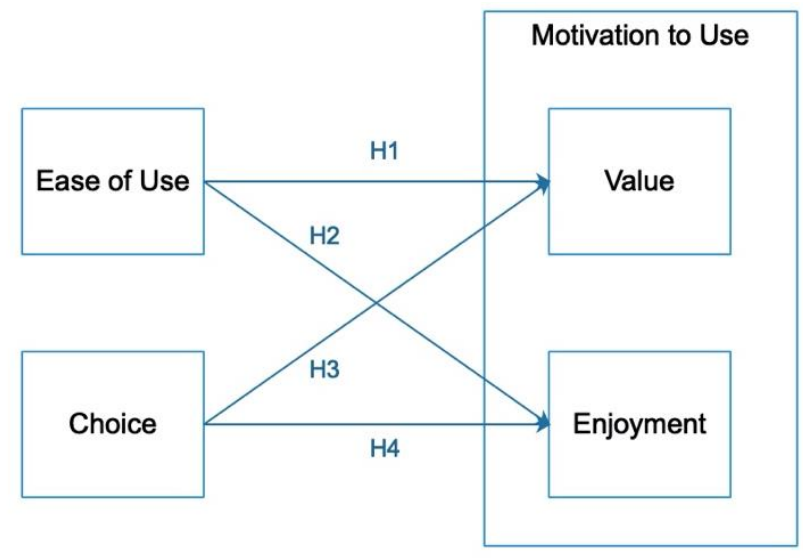

Figure 1. Research

Model

Perceived ease of use is the notion that the user will have to expend little effort to use the system. ${ }^{19-20}$ Perceived ease of use was developed in the field of information systems and has been used to study gamification within business settings. 19-21 Perceived ease of use is well established in the information systems literature as influencing both perceived usefulness of a system and their motivations/intentions to use the system. ${ }^{20}$ In alignment with findings in the gamification literature, we posit that in this setting:

H1: Ease of use will positively impact the value students experience in using the gamification system.

H2: Ease of use will positively impact the enjoyment students experience in using the gamification system.
Choice relates to Universal Design for Learning and providing students with options regarding their work in the system, the methods used to accomplish it, and its link to their background. ${ }^{18}$ Ultimately, giving students choices regarding the tasks they complete, the process for completing them, etc. may have a positive relationship with their motivation to use the system. If students are more motivated to use the system, they will get more exposure to the material, which can enhance student learning outcomes. As such, we submit that:

H3: Choice will positively impact the value students experience in using the gamification system

H4: Choice will positively impact the enjoyment students experience in using the gamification system. 


\section{METHODS}

\section{Classcraft ${ }^{\oplus}$ Design}

Gamification was used in a first-year course at a U.S. Midwest school of pharmacy. Approximately 80 students were registered for the course. The execution of Classcraft $^{\oplus}$ was a collaboration between the Pharmaceutical Sciences professor and a professor from the Computer Management \& Information Systems Department in the School of Business with experience in gamification. The Pharmaceutical Sciences professor and a Masters in Pharmaceutical Sciences student were responsible for the course content that was used. The Information Systems professor was responsible for setting up and overseeing the use of the Classcraft ${ }^{\circledR}$ system.
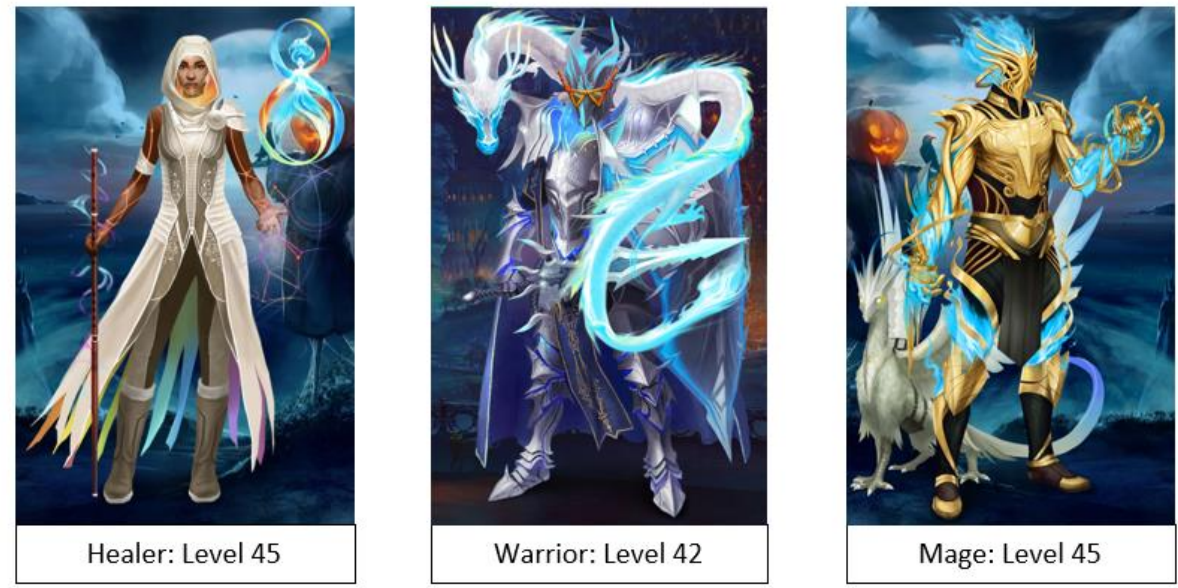

Figure 2. Classcraft ${ }^{\circledast}$ Roles
Students were asked to self-select teams of four students. Within Classcraft ${ }^{\oplus}$ each team students then decided who would play each role: mage, warrior, or healer. Examples of each of the three roles are shown in Figure 2. Each student's character started at Level 1 (as is the case with most video games) and through a variety of actions within the gamified system, they increased the level of their individual character. They also received gold within the game, which they could use to buy clothing/gear for their character. Additionally, they could acquire a pet that they sent out on missions and which brought them back gold and items.
Each character had four attributes: health points (HP), action points (AP), experience points (XP), and gold pieces (GP). Health points were the life points of the character, which are increased/depleted by attacks from bosses and actions of other players. Action points allow the use of powers and were gained by resting, leveling, and actions of other players. They were depleted by the use of powers. Gold pieces were the amount of gold the student had earned through system actions, behaviors, or boss battle wins. Experience points were gained through positive behaviors executed within the system or external to the system, but which instructors set up for reward in the class. Behaviors set up for this course and the reward for each are shown in Table 1.

Table 1. Available Behavior Rewards

\begin{tabular}{ccc}
\hline $\begin{array}{c}\text { Reward } \\
\text { Type }\end{array}$ & $\begin{array}{c}\text { Reward } \\
\text { Amount }\end{array}$ & $\begin{array}{c}\text { Behavior } \\
\text { Description }\end{array}$ \\
\hline XP & +25 & Play Classcraft each week \\
XP & +25 & Train your pet each week \\
GP & +10 & Play Classcraft each week \\
GP & +50 & Handing in assignment 24 hours early \\
GP & +50 & Use a power to help a teammate at least once a week \\
\hline
\end{tabular}

At the end of each week the information systems instructor reviewed each students' game play in the system. Based upon the students' execution of behaviors defined in Table 1, experience points and/or gold pieces were awarded.

The powers for each class are shown in Table 2. Each class (mage, healer, warrior) could acquire various powers through game play. Some of those powers were preset by the
Classcraft $^{\circledR}$ system. Others were created/defined by the Information Systems instructor to encourage game play. The higher a player's level, the more power they acquire and the action points they have at their disposal to use in game play and during boss battles. Thus, engaging in activities that raised their level, such as training a pet and playing Classcraft each week, increased their opportunity to use powers that could aid them with assignments and boss battles. 
Table 2. Individual Character Powers

Power Name

Description

System Instructor

Preset

Defined

\begin{tabular}{|c|c|c|c|}
\hline \multicolumn{4}{|l|}{ Mage } \\
\hline Mana Transfer & All team member, except Mages, gain $7 \mathrm{AP}$ & $\mathrm{x}$ & \\
\hline Teleport & The Mage can ask other teammates to help answer a question during a Boss Battle & & $\mathrm{x}$ \\
\hline Famine & The Mage and their team members all get a treat during a Boss Battle & & $\mathrm{x}$ \\
\hline Mana Shield & The Mage prevents the loss of HP to themselves (costs $3 \mathrm{AP}$ per $1 \mathrm{HP}$ ) & $x$ & \\
\hline Time Warp & $\begin{array}{l}\text { During a Boss Battle, the healer can ask the game master if his/her answer is correct } \\
\text { before giving their final answer }\end{array}$ & & $\mathrm{x}$ \\
\hline Fountain of Mana & A teammate, who isn't a Mage, replenishes all of their AP & $\mathrm{x}$ & \\
\hline Clairvoyance & $\begin{array}{l}\text { During a Boss Battle, the Mage changes a Wrong Answer to a Correct Answer with a } \\
\text { special attack }\end{array}$ & & $x$ \\
\hline Mage Circle & $\begin{array}{l}\text { The Mage can choose to turn in an assignment one day late OR make up a missed } \\
\text { assignment }\end{array}$ & & $\mathrm{x}$ \\
\hline \multicolumn{4}{|c|}{ Th } \\
\hline Protect 1 & $\begin{array}{l}\text { The Warrior can take up to } 10 \text { damage instead of their teammate, receiving only } \\
80 \% \text { of the initial damage }\end{array}$ & $x$ & \\
\hline First Aid & Warrior gains $1 \mathrm{HP}$ for each level they have, but always gains at least $5 \mathrm{HP}$ & $\mathrm{x}$ & \\
\hline Hunting & $\begin{array}{l}\text { The Warrior can search for an answer to a Boss Battle question by asking other } \\
\text { teams to help }\end{array}$ & & $\mathrm{x}$ \\
\hline Protect 2 & $\begin{array}{l}\text { The Warrior can take up to } 20 \text { damage instead of their teammates, receiving only } \\
65 \% \text { of the initial damage }\end{array}$ & $\mathrm{x}$ & \\
\hline Ambush & The Warrior and their team members all get a treat during a Boss Battle & & $x$ \\
\hline Counter Attack & $\begin{array}{l}\text { During a Boss Battle, the Warrior can ask the game master if his/her answer is } \\
\text { correct before giving their final answer }\end{array}$ & & $x$ \\
\hline Protect 3 & $\begin{array}{l}\text { The Warrior can take up to } 30 \text { damage instead of their teammate, receiving only } \\
50 \% \text { of the initial damage }\end{array}$ & $x$ & \\
\hline Frontal Assault & $\begin{array}{l}\text { During a Boss Battle, the Warrior changes a Wrong Answer to a Correct Answer with } \\
\text { a special attack }\end{array}$ & & $x$ \\
\hline Secret Weapon & $\begin{array}{l}\text { The Warrior can choose to turn in an assignment one day late OR make up a missed } \\
\text { assignment }\end{array}$ & & $\mathrm{x}$ \\
\hline \multicolumn{4}{|l|}{ Healer } \\
\hline Heal 1 & A teammate gains $10 \mathrm{HP}$ & $\mathrm{x}$ & \\
\hline Sainthood & $\begin{array}{l}\text { The Healer can conjure an answer to a Boss Battle question by asking other teams to } \\
\text { help }\end{array}$ & & $\mathrm{x}$ \\
\hline Ardent Faith & $\begin{array}{l}\text { During a Boss Battle, the Healer can ask the Gamemaster if their answer to a } \\
\text { question is correct }\end{array}$ & & $\mathrm{x}$ \\
\hline Heal 2 & A teammate gains $20 \mathrm{HP}$ & $\mathrm{x}$ & \\
\hline Favor of the Gods & The Healer and their team members all get a treat during a Boss Battle & & $x$ \\
\hline Revive & $\begin{array}{l}\text { When a teammate (not including the Healer) falls to } 0 \mathrm{HP} \text {, they avoid all penalties } \\
\text { and come back to life with } 1 \mathrm{HP}\end{array}$ & $\mathrm{x}$ & \\
\hline Heal 3 & A teammate gains $30 \mathrm{HP}$ & $x$ & \\
\hline Healing Circle & All team members, other than the Healer, gain $15 \mathrm{HP}$ & $x$ & \\
\hline Prayer & $\begin{array}{l}\text { The Healer can choose to turn in an assignment one day late OR make up a missed } \\
\text { assignment }\end{array}$ & & $x$ \\
\hline
\end{tabular}


In addition to behaviors and powers, two content driven features were utilized within the Classcraft ${ }^{\circledR}$ system: quests, boss battles. Quests were the homework assignments that students completed in teams. Participants followed the storyline of two characters, who engaged in conversations regarding the content for each assignment. The storyline was presented in videos that were created by the information systems instructor and based on each assignment. Figure 3 shows the quest process.
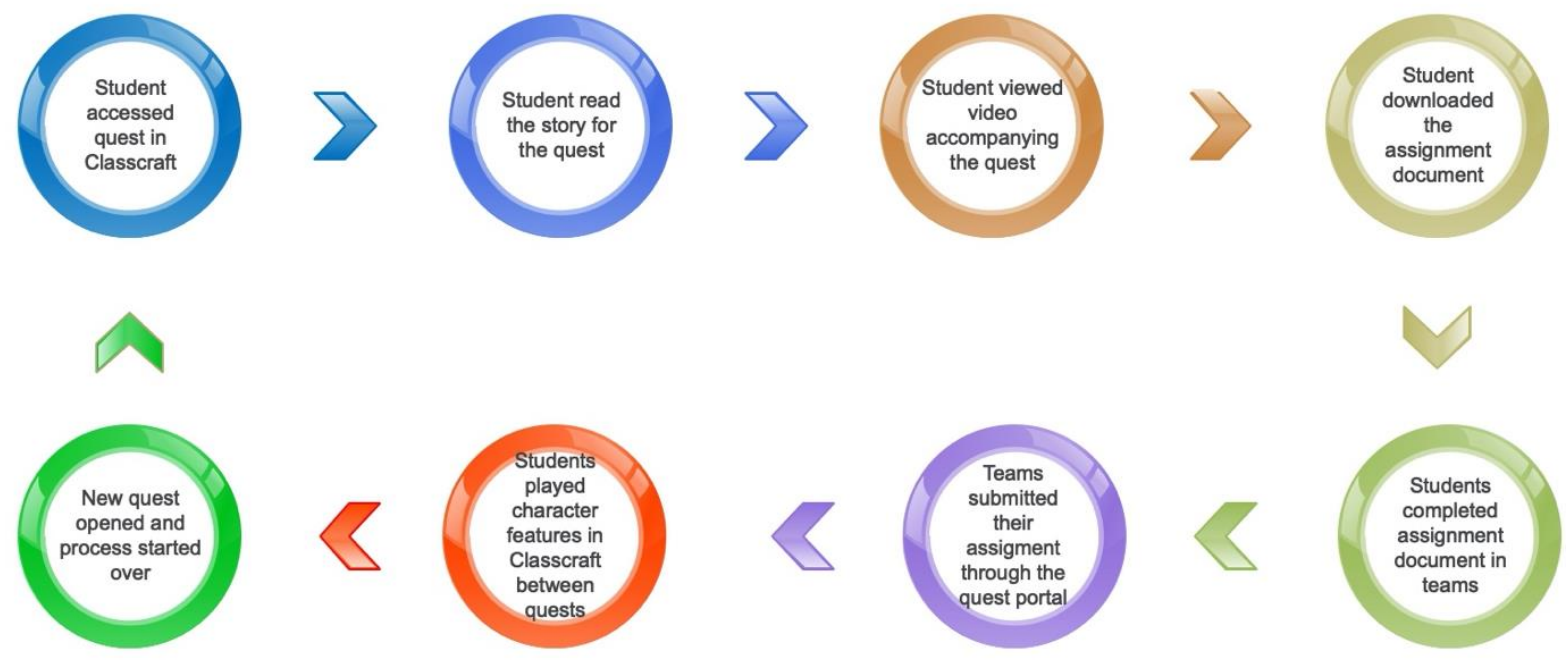

Figure 3. Student Quest Process in Classcraft ${ }^{\circledR}$

The content of the quests was directly related to the course materials. For example, the first quest consisted of four multiple choice questions and one short answer:

1. The formation of memory immune responses is the objective of vaccination. Immunological memory is predominantly the function of which of the following?

2. When a woman whose blood type is Rh negative is pregnant, she is given rho immune globulin to prevent sensitization to an Rh positive fetus. This is an example of which of the following?

3. You enter a dusty room, feel an itch in your nose, and sneeze. This is an example of the operation of which of the following innate immune mechanisms?

4. When an individual encounters Gram-negative bacteria (if the organisms survive the physical and chemical barriers), they may be recognized on first encounter by the innate immune system via which of the following?

5. Describe the process of extravasation, including the receptors and cell adhesion molecules involved.

In addition to the assignments completed through quests, the Pharmaceutical Sciences professor provided practice test questions for three boss battles during the semester. Boss battles are formative reviews that were conducted interactively with students in the classroom two days prior to the exams. Three boss battles were executed over the course of the semester. The first battle consisted of 30 questions, the second 28 questions, and the third 22 questions. Each question was worth $100-150$ health points and if the students got it right, they would take health away from the boss. The pedagogical goal was for students to be able to answer the questions correctly and gain an understanding of the areas they need to study for the test. Questions were a mix of true/false, multiple choice, and short answer. The system allowed for the inclusion of images with questions when necessary. Examples of questions included on the boss battles are:

1. Give an example of a specific pathogen that would undergo Exogenous Antigen Processing and the MHC that would bind to it.

2. What is integrin?

3. Your 5-year old cousin has a genetic defect that impairs her B-cell maturation. Which of the following does she most likely have?

4. A patient with B cell lymphoma is receiving therapy aimed at targeting the surface antibody expressed on his tumor cells. Used in this way, this antibody is an example of:

5. Bone marrow transplantation in immunocompromised patients presents which major problem?

The Information Systems instructor set up the practice test questions in the Classcraft ${ }^{\circledR}$ system. Then, in the classroom, the Classcraft ${ }^{\circledR}$ system was displayed on screens for all students to view. Questions were displayed and the system randomly chose teams to answer them. Figure 4 shows the screen as seen by students during a boss battle. If the teams answered enough questions correctly, they defeated the boss in the Classcraft ${ }^{\circ}$ system, and their in-game characters received a reward. 


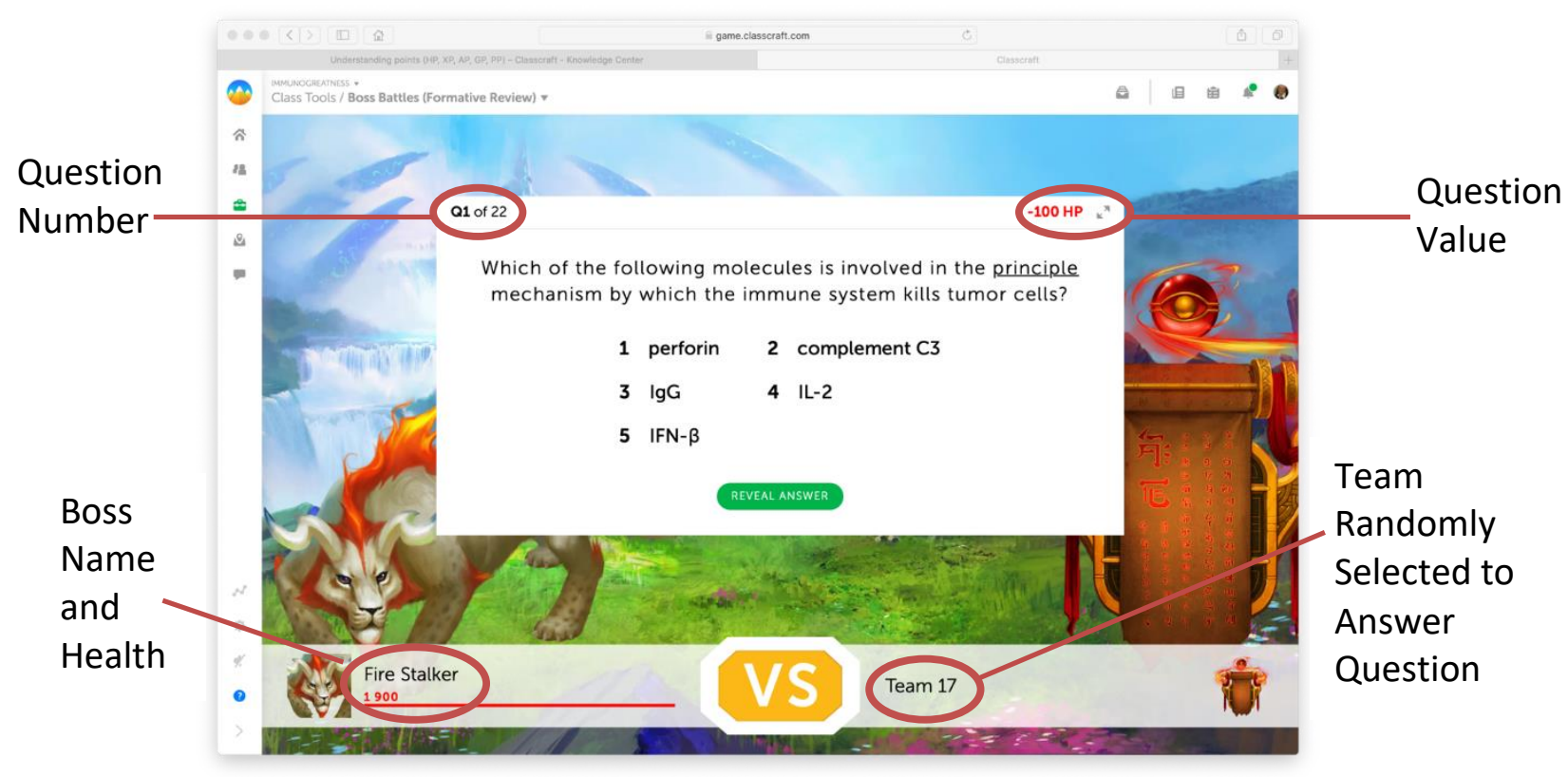

Figure 4. Classcraft ${ }^{\oplus}$ Boss Battle Example

To support the success during boss battles, each character (mage, healer, warrior) could execute powers from Table 2 that they had acquired during gameplay within the Classcraft $^{\circ}$ system. For example, warriors had a power that, if played in the Classcraft $^{\oplus}$ system, would allow the team who played it to change a wrong answer to a correct answer during a boss battle. These powers were played by students on their own time during the weeks leading up to a boss battle. It was a mechanism for motivating game play.

\section{Research Measures}

All four constructs (perceived ease of use, choice, value, and enjoyment) were measured using 5-point Likert scale responses. Specifically, perceived ease of use was operationalized by asking students about their perceptions regarding the use of Classcraft ${ }^{\oplus}$ via measures adapted from Ong et al. for impact on intention to use. ${ }^{16}$ Choices captured students' perspectives about the options regarding tasks they completed within Classcraft ${ }^{\oplus}$ and were measured with items adapted from Gentry et al. as applied to student perceptions of classroom activities. ${ }^{24}$ Value was operationalized through measuring the value and usefulness students attributed to the Classcraft ${ }^{\oplus}$ system. ${ }^{16-17}$ Enjoyment was measured with respect to students' perceptions of the enjoyability, challenge, and interest level regarding the Classcraft ${ }^{\oplus}$ system. ${ }^{24}$ The selected items were randomized on the surveys to minimize the effect of common method bias.

\section{Data Collection}

In order to capture student perspectives on ease of use, choice, and motivation to use the system, four surveys were administered across the 16 weeks of the semester. The first survey was administered prior to student use of Classcraft ${ }^{\circledR}$. Each of the subsequent surveys followed a boss battle (exam review) with the fourth survey given right before final exams. Qualtrics survey software (SAP, Walldorf, BadenWürttemberg, Germany) was used to administer the surveys. All students were offered the opportunity to complete the surveys and each was worth 5 points. The total possible course points were 500 with 100 of those being the quests completed in Classcraft ${ }^{\circledR}$. Student names were captured for purposes of awarding the points for completion, but were removed prior to data analysis. Some students opted not to complete the survey and/or skipped questions, which created incomplete records. After cleaning the data responses, we had 53 usable student records across all four surveys. Of the respondents, 47 (89\%) were between the ages of 18 and 24 . The remaining respondents were between 25 and 34 years of age. Also, although two respondents listed themselves as employed in the business sector, the majority $(46-87 \%)$ identified being a student as their current employment situation. Four respondents were unemployed, and one listed themselves as other.

Additionally, a variety of questions were asked to gauge the students' comfort level with video games and using games for learning. First, respondents were asked how frequently they played video games and, if they do play them, what was the reason. Table 3 includes student responses. The majority of students indicated that they rarely or never play video games. 
Table 3. Video Game Play Among Students

\begin{tabular}{lc}
\hline \multicolumn{1}{c}{ Item/Responses } & Percentage of Respondents (N=53) \\
\hline Video Game Play Frequency & 15 \\
Daily & 13 \\
Weekly & 15 \\
Monthly & 36 \\
Rarely & 21 \\
Never & \\
Why Play Video Games* & 19 \\
To play with others & 23 \\
Mental challenge & 5 \\
Physical challenge & 30 \\
Boredom & 10 \\
To make social connections & 3 \\
Other & 10 \\
None & \\
\hline
\end{tabular}

* Respondents could select all answers that applied to them

To examine using a video game for learning versus playing them for fun, interest in using a video game for learning and whether its use caused any anxiety were evaluated. The results are shown in Table 4.

Table 4. Student Interest in and Anxiety about Video Games for Learning

\begin{tabular}{lc}
\hline & $\begin{array}{c}\text { Percentage of Respondents } \\
\mathbf{N}=53\end{array}$ \\
\hline Interest in Video Games for Learning & \\
Extremely interested & 11 \\
Interested & 21 \\
Neutral & 30 \\
Disinterested & 21 \\
Extremely disinterested & 17 \\
Anxiety about Video Games for Learning & \\
Describes me extremely well & 4 \\
Describes me very well & 11 \\
Describes me moderately well & 8 \\
Describes me slightly well & 25 \\
Does not describe me & 53 \\
\hline
\end{tabular}

\section{Analytical Process}

The initial step of the analytical process was extraction of data from the Qualtrics survey software and the Classcraft ${ }^{\circledR}$ gamification system, which included player levels and all player actions logged in the system (e.g. using powers, training pets, purchasing gear, completing quests). Data was aggregated between the systems to create one data record for each student. Incomplete records were removed from the data set. SmartPLS 3 (SmartPLS GmbH, Germany) was used for structured equation modeling ${ }^{21}$. Construct loadings were tested to ensure that the items on the survey were significant to the construct it is measuring and not to any other construct. A t-test with a result of .7 or greater indicates significant loadings and thus the validity of each construct in the model. ${ }^{25}$
The composite reliability of each construct was tested in the model by applying confirmatory factor analysis. This ensured the internal consistency of each construct with an expected result of .7 or greater. ${ }^{25}$ Lastly, a Fornell-Larcker test was used to ensure both convergent and divergent validity of the model. This test "compares the square root of the average variance extracted (AVE) with the correlation of latent constructs. A latent construct should explain better the variance of its own indicator rather than the variance of other latent constructs. Therefore, the square root of each construct's AVE should have a greater value than the correlations with other latent constructs." 25 
Once the measurement model was assessed the model was run to check the path coefficients and look for significance between the constructs. T-tests were applied with resulting $p$-values to identify significant relationships with a $p$-value $<.05$ identifying significance. Additionally, we conducted $\mathrm{R}^{2}$ tests to determine the percentage of dependent variables' variance explained by the independent variables. Data was collected with approval from the Institutional Review Board at Southern Illinois University Edwardsville.

\section{RESULTS}

\section{Measurement Model}

Item construct loadings and reliabilities are shown in Table 5. Construct validity is established, as all item construct loadings are above the .7, which indicates that "the construct explains more than 50 percent of the indicator's variance." 21 Additionally, composite reliability of all four constructs is demonstrated, as they considerably exceed the .7 standard. ${ }^{22}$

Table 5. Items, Construct Loadings, and Reliability

\begin{tabular}{|c|c|c|}
\hline Items & $\begin{array}{l}\text { Item-Construct } \\
\text { Loadings }\end{array}$ & $\begin{array}{l}\text { Composite } \\
\text { Reliability }\end{array}$ \\
\hline Ease of Use & & 0.916 \\
\hline My intention with the Classcraft ${ }^{\circledast}$ system is clear and understandable. & 0.866 & \\
\hline $\begin{array}{l}\text { Interacting with the Classcraft }{ }^{\oplus} \text { system does not require a lot of mental } \\
\text { effort. }\end{array}$ & 0.724 & \\
\hline I find the Classcraft ${ }^{\oplus}$ system to be easy to use. & 0.921 & \\
\hline I find it easy to get the Classcraft ${ }^{\otimes}$ system to do what I want it to do. & 0.898 & \\
\hline Choice & & 0.911 \\
\hline I can choose my own tasks within Classcraft ${ }^{\circledR}$. & 0.904 & \\
\hline $\begin{array}{l}\text { Where there are many tasks in Classcraft }{ }^{\circ}, \text { I can choose the ones that suit } \\
\text { me. }\end{array}$ & 0.862 & \\
\hline I can choose materials to work with in Classcraft ${ }^{\circledR}$. & 0.866 & \\
\hline I can choose the audience for my product. & 0.755 & \\
\hline Value & & 0.984 \\
\hline I believe that Classcraft ${ }^{\oplus}$ is useful for improved concentration. & 0.955 & \\
\hline I believe that Classcraft ${ }^{\oplus}$ is important for my improvement. & 0.971 & \\
\hline Using the Classcraft ${ }^{\circledR}$ system improves my course performance. & 0.968 & \\
\hline Using the Classcraft ${ }^{\oplus}$ system enhances my effectiveness in the course. & 0.932 & \\
\hline Using the Classcraft ${ }^{\circledR}$ system in my course improves my productivity. & 0.98 & \\
\hline Enjoyment & & 0.957 \\
\hline I look forward to Classcraft ${ }^{\circledR}$. & 0.906 & \\
\hline I like what I do in Classcraft ${ }^{\circ}$. & 0.944 & \\
\hline The activities I do in $\mathrm{Classcraft}^{\circ}$ are enjoyable. & 0.926 & \\
\hline I have to think to solve problems in Classcraft ${ }^{\circledR}$. & 0.723 & \\
\hline What we do in Classcraft ${ }^{\oplus}$ fits my abilities. & 0.772 & \\
\hline What I do in Classcraft ${ }^{\circledR}$ fits my interests. & 0.935 & \\
\hline I study interesting topics in Classcraft ${ }^{\circledR}$ & 0.874 & \\
\hline
\end{tabular}

The Fornell-Larcker method was used to evaluate discriminant validity. Table 6 shows the composite reliability, average variance extracted (AVE), and correlation coefficients for each construct. All four constructs have an AVE above .7, thus convergent validity is considered very good. ${ }^{21}$ Combined with the correlation coefficients, discriminant validity was achieved.

Table 6. Discriminant Validity Results

\begin{tabular}{lcccccc}
\hline & CR* & AVE** & Choice & Ease of Use & Enjoyment & Value \\
\hline Choice & 0.911 & 0.720 & 0.848 & & & \\
Ease of Use & 0.916 & 0.732 & 0.424 & 0.856 & & \\
Enjoyment & 0.957 & 0.761 & 0.614 & 0.686 & 0.872 & 0.961 \\
Value & 0.984 & 0.924 & 0.761 & 0.434 & 0.803 & 0.961 \\
\hline
\end{tabular}

*Composite reliability: internal consistency of each construct

**Average variance extracted: greater value of own construct than other constructs 


\section{Structural Model}

We used Smart PLS (SmartPLS GmbH, Germany) to evaluate the structural model. ${ }^{21}$ First, the resulting t-statistic for each relationship hypothesized was obtained and their coefficients noted in Figure 5. Additionally, we identified the predictive accuracy of Value and Enjoyment as moderate to strong because the constructs have $R^{2}$ percentages of 59.4 and 59.8 respectfully. ${ }^{27}$

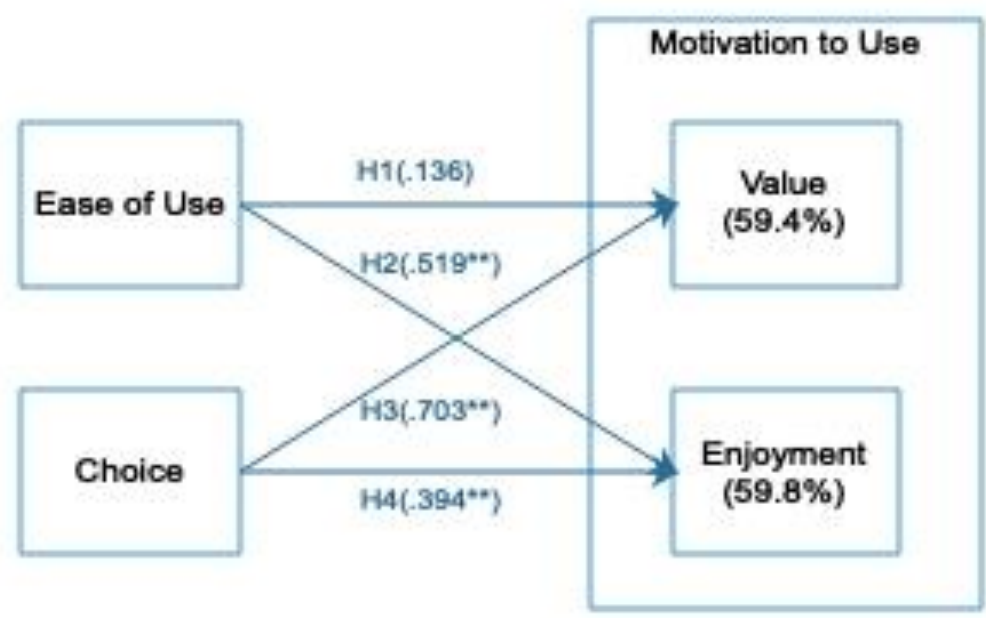

Hypotheses significance identified by t-statistic path coefficient Significance is defined as $p<.05$, path coefficients with ${ }^{* *}$ are $p<.001$

Figure 5. Results of Research Model

Table 7 presents the hypothesized relationships, path coefficients with $p$-values, and whether or not each was supported.

Table 7. Hypotheses and Results

\begin{tabular}{lcc}
\hline \multicolumn{1}{c}{$\begin{array}{c}\text { Relationships Hypothesized for } \\
\text { Students Using a Gamification System }\end{array}$} & $\begin{array}{c}\text { Path Coefficients } \\
(\boldsymbol{p} \text {-values })\end{array}$ & $\begin{array}{c}\text { Supported } \\
(\boldsymbol{p}<.05)\end{array}$ \\
\hline H1: Ease of use will positively impact the value students experience & $.136(.280)$ & No \\
H2: Ease of use will positively impact the enjoyment students experience & $.519(.000)$ & Yes \\
H3: Choice will positively impact the value students experience & $.703(.000)$ & Yes \\
H4: Choice will positively impact the enjoyment students experience & $.394(.000)$ & Yes \\
\hline
\end{tabular}

In addition to the tested relationships, the data extracted from the Classcraft $^{\circledR}$ system provided a picture of student engagement with the system. Figure 6 provides a visualization of a student-created character in Classcraft $^{\circledR}$ along with statistics regarding student engagement with the system outside of the classroom. These statistics were gathered based upon the number of times that students logged into the system and engaged in actions like using powers, training their pet, purchasing gear, and completing quests. Half of the students completed the minimum amount of engagement required, which was reviewing the assignment content and completing the quests. Through these in-game actions and the boss battles students could minimally raise the level of their characters. The average level of those who did only what was required was in the 20 s. Yet, $38 \%$ of the students competed actions in the system that leveled their characters in the 35-45 range. They spent time just using powers, training their pets, and other actions in the system. These students truly engaged in the game play aspects of the system. 


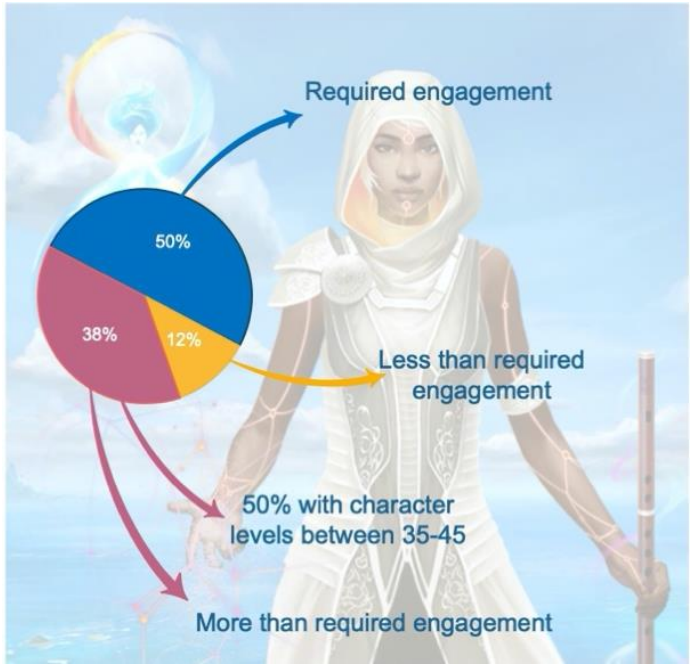

Figure 6. Student Engagement with Classcraft $^{\circledR}$ Outside of the Classroom

\section{DISCUSSION}

Research in gamification has shown that, when used properly, a gamified system can be a powerful method of stimulating student learning outcomes. ${ }^{12}$ However, before those outcomes can be actualized, students must be motivated to use the system. Two indicators of motivation to use a gamified system are value and enjoyment. ${ }^{11-13}$ We observed that in the case of Classcraft ${ }^{\oplus}$ being used in an immunology training course, these two factors can explain students' motivation to use the system. Kamboj et al., found that enjoyment positively impacted consumer's engagement with a gamified system. ${ }^{29}$ However, in their study perceived ease of use also positively impacted consumer engagement with a gamified system. In contrast, we identified that perceived ease of use has a positive impact on enjoyment as a motivational factor to use a gamified system in higher education.

Similarly, Huang et al. found that perceived ease of use and value positively impacted user satisfaction with a gamified system. ${ }^{30}$ While we determined that students were motivated by the value they identified in the system, perceived ease of use did not significantly impact that value. To complete assignments in Classcraft $^{\circledR}$, students downloaded a Microsoft Word (Redmond, Washington, USA) document, filled it in and then uploaded it back to the system. Due to these steps, when asked to provide additional feedback on the system, some students commented that it seemed like just another learning management system (i.e. Blackboard, Canvas, etc.). Thus, the ease with which students were able to complete the steps may not have added to the value of using the system.

While students were required to use the system minimally to engage with their team to submit assignments and participate in boss battles, they were not required to play powers or engage with the system in other ways during the weeks. The freedom to choose was evidenced as impacting the value and enjoyment they experienced. Student choice in using the system did positively impact value. It can be ascertained that this relationship is significant for pedagogical reasons. The instructor required that students engage with the Classcraft ${ }^{\oplus}$ system, at least minimally. This requirement inherently created value that was directly related to the system in that the students' ability to complete assignments was impacted by their use of the system. This type of value is not inherent in mobile game apps or fitness apps. It does generate questions around the use of gamification in employment settings. For example, if the use of a gamified system was required for Title IX training, would the relationship between choice and value be significant? Additionally, as previously noted, $38 \%$ of students engaged with the system beyond the minimum requirements. Their choice to do so could be the significant relationship with enjoyment as the more they played the greater than enjoyment.

The differences between our study and those mentioned may be context. While we examined motivations to use a gamified system in higher education, the aforementioned studies were conducted with a fitness app (Huang et al. ${ }^{30}$ ) and mobile game apps (Kamoj et al. ${ }^{29}$ ). The motivation to use those types of apps differs from educational gamified systems in both the reasons for use and the value seen in them.

So, what does this mean for instructors teaching courses like Immunology and Immunization Training? It is evident that students found value and enjoyment in using the gamified system. Like Dell and Chudow, who used gaming in their Pharmacotherapeutics course, we felt that participating in the review session was a low-stakes activity for students since it did not count towards their course grade. ${ }^{6}$ The immediate feedback from the game results and the interactivity/competition helped prepare them for the upcoming tests. Student comments on the assessments were reflective of this. While a disadvantage of the review sessions could be the potential to cause anxiety and embarrassment ${ }^{6}$, students did not express this in the assessments. However, this could vary, depending on the collegiality of student classes. 
As previously noted, only minimal engagement with the system was required. However, character levels at the end of the course indicated that over one-third of students engaged with the system voluntarily beyond the requirements. This encourages research questions such as "how do gamified learning systems impact learning outcomes in immunology and immunization training?" and "what elements of gamified learning systems motivate students in immunology and immunization training?" One aspect of this study that limits its generalizability was its application in one course with roughly 80 students in the spring of 2019. As Dell et al. was able to identify that student performance of review games significantly correlated with course grades, we encourage further study of the Classcraft $^{\circledR}$ system and its impact on student learning. ${ }^{6}$

In summary, the use of Classcraft in an Immunology and Immunization training course revealed that both value and enjoyment in the system motivated students to use it. Additionally, perceived ease of use positively impacted the enjoyment that students found in the system. The amount of choice that students had in using the system impacted both the value and enjoyment they get in using it. These findings both add to the extant literature on gamification and indicate the need for further research, including examining the aspects of gamified systems and the courses in which they are used for impact on student motivation to learn, as well as gamification's impact on student learning in pharmaceutical science classrooms.

Funding: This research was supported by a Southern Illinois University Edwardsville Innovation Grant.

\section{Conflicts of interest: None}

\section{REFERENCES}

1. Dimock M. Where Millennials end and Generation Z begins. Pew Res Cent. 2019:1-8. http://www.pewresearch.org/facttank/2019/01/17/where-millennials-end-andgeneration-z-begins/ Accessed October 15, 2020.

2. Grady SE, Vest KM, Todd TJ. Student Attitudes Toward the Use of Games to Promote Learning in the Large Classroom Setting. Curr Pharm Teach Learn. 2013;5(4):263-268. doi:10.1016/J.CPTL.2013.01.008.

3. Begley KJ, Monaghan MS, Clavier CW, Lugo RA, Crouch MA. Technology in the Pharmacy Learning Environment: Surveys of Use and Misuse. Inov Pharm. 2015;6(186):1-11 doi:10.24926/iip.v6i1.368.

4. Shawaqfeh MS. Gamification as a Learning Method in Pharmacy Education. J Pharma Care Heal Sys. 2015:S2-004. doi:10.4172/jpchs.S2-004.

5. Sera L, Wheeler E. Game on: The Gamification of the Pharmacy Classroom. Curr Pharm Teach Learn. 2017; 9(1):155-159 doi:10.1016/j.cptl.2016.08.04.
6. Dell KA, Chudow MB. A Web-based Review Game as a Measure of Overall Course Knowledge in Pharmacotherapeutics. Curr Pharm Teach Learn. 2019;11(8):838-842. doi:10.1016/j.cptl.2019.04.012.

7. Cain J, Piascik P. Are Serious Games a Good Strategy for Pharmacy Education? Am J Pharm Educ. 2015;79(4):47. doi:10.5688/ajpe79447.

8. Lam JT, Gutierrez MA, Goad JA, Odessky L, Bock J. Use of Virtual Games for Interactive Learning in a Pharmacy Curriculum. Curr Pharm Teach Learn. 2019;11(1):51-57. doi:10.1016/j.cptl.2018.09.012.

9. Hookham G, Nesbitt K, Cooper J, Croft H, Rasiah R. Gamification for Education: Designing Pharmacy Education Game. Artificial Life and Computational Intelligence: First Australasian Conference, ACALCl, 2015 2, Newcastle, NSW, Australia, February 5-7, 2015, Proceedings, Springer International Publishing, Switzerland(2015), pp.157-165.

10. doi:10.1007/978-3-319-14803-8_12.

11. Muntean, C. I. 2011. "Raising Engagement in ELearning through Gamification," in The 6th International Conference on Virtual Learning ICVL 2011, pp. 323-329.

12. Nicholson, S. 2012. A user-centered theoretical framework for meaningful gamification. Paper presented at the Games+ Learning+ Society. 8.0, Madison, WI, USA.

13. Putz, L.-M., and Treiblmaier, H. 2015. "Creating a Theory-Based Research Agenda for Gamification," AMCIS 2015 Proceedings (1), pp. 1-13.

14. Reiners, T., Wood, L. C., Chang, V., Gütl, C., Herrington, J., Teräs, H., and Gregory, S. 2012. "Operationalising Gamification in an Educational Authentic Environment," in IADIS International Conference on Internet Technologies \& Society, pp. 93-100. http://hdl.handle.net/10292/6204. Accessed October 26, 2020.

15. Schunk, D. H., and Dibenedetto, M. K. 2016. "SelfEfficacy Theory in Education," in Handbook of Motivation in School, pp. 34-54. https://www.routledgehandbooks.com/doi/10.4324/ 9781315773384.ch3. Accessed October 26, 2020.

16. Gamification in Education. Classcraft ${ }^{\circledR}$ Website. https://www.Classcraft ${ }^{\circledR}$.com/gamification/. Accessed October 25, 2020.

17. Ong CS, Lai JY, Wang YS. Factors Affecting Engineers' Acceptance of Asynchronous e-learning Systems in High-tech Companies. Inf Manag. 2004;41(6):795804. doi:10.1016/j.im.2003.08.012.

18. Deci EL, Eghrari H, Patrick BC, Leone DR. Facilitating Internalization: The Self-Determination Theory Perspective. J Pers. 1994;62(1):119-142. doi:10.1111/J.14676494.1994.TB00797.X. 
19. Ghani JA, Supnick R, \& Rooney P. The Experience of Flow in Computer-Mediated and in Face-to-Face Groups. In ICIS 1991 Proceedings (pp. 229-237). https://www.researchgate.net/publication/22159933 6_The_Experience_Of_Flow_In_ComputerMediated_And_In_Face-To-Face_Groups. Accessed October 14, 2020.

20. Fang $X$, Zhao F. Personality and Enjoyment of Computer Game Play. Comput Ind. 2010;61(4):342349. doi:10.1016/J.COMPIND.2009.12.005.

21. Lai P. The Literature Review of Technology Adoption Models and Theories for the Novelty Technology. J Inf Syst Technol Manag. 2017;14(1):21-38. doi:10.4301/s180717752017000100002.

22. Venkatesh V, Bala H. Technology Acceptance Model 3 and a Research Agenda on Interventions. Decis Sci. 2008;39(2):273-315. doi:10.1111/J.15405915.2008.00192.X.

23. Rodrigues LF, Costa CJ, Oliveira A. The Adoption of Gamification in e-banking. Proc 2013 Int Conf Inf Syst Des Commun. 2013:47-55. doi:10.1145/2503859.2503867.

24. Nicholson S. A User-Centered Theoretical Framework for Meaningful Gamification. Published in 2012. http://becauseplaymatters.com. Accessed October 15, 2020.

25. Gentry M, Gable RK, Rizza MG. Students' Perceptions of Classroom Activities: Are There Grade-level and Gender Differences? J Educ Psychol. 2002;94(3):539544. doi:10.1037/0022-0663.94.3.539.
26. Hamid MRA, Sami W, Sidek MHM. Discriminant Validity Assessment: Use of Fornell \& Larcker Criterion versus HTMT Criterion. J. Phys.: Conf. Ser. 2017; 890:3. doi :10.1088/1742-6596/890/1/012163

27. Ringle CM, Wende $S$, \& Becker JM. SmartPLS 3. Published in 2015. Bönningstedt: SmartPLS. http://www.smartpls.com. Accessed October 15, 2020.

28. Hair JF, Risher JJ, Sarstedt M, Ringle CM. When to Use and How to Report the Results of PLS-SEM. Eur Bus Rev. 2019;31(1):2-24. doi:10.1108/EBR-11-20180203.

29. Sarstedt $M$, Ringle $\mathrm{CM}$, Cheah JH, Ting $\mathrm{H}$, Moisescu OI, Radomir L. Structural Model Robustness Checks in PLS-SEM. Tour Econ. 2019:1-24. doi:10.1177/1354816618823921.

30. Kamboj, S., Rana, S., \& Drave, V. A. (2020). Factors Driving Consumer Engagement and Intentions with Gamification of Mobile Apps. JECO, 18(2), 17-35. https://doi.org/10.4018/jeco.2020040102 30.

31. Huang, C. K., Chen, C. Der, \& Liu, Y. T. (2019). To Stay or Not to Stay? Discontinuance Intention of Gamification Apps. IT \& P, 32(6), 1423-1445. https://doi.org/10.1108/ITP-08-2017-0271 